\title{
AL-KHAWARIJ DAN AL-MURJIAH \\ ( Sejarah Timbulnya dan Pokok-pokok Ajarannya)
}

\author{
Oleh : Muh. Anis ${ }^{1}$
}

\section{Pendahuluan}

Pada waktu Nabi Muhammad Saw. Bersatu bulat dalam segala-galanya. Tidak ada aliran dan mazhab pada waktu itu, apakah aliran atau mazhab dalam bidang Fiqhi maupun dalam bidang Teologi. Nabi merupakan kesatuan sumber dalam lmu dan amal, dalam perintah dan ketaatan, uswatun hasanah: suri teladan dalam kehidupan. Jika kaum muslim berbantah dan berbeda paham dalam sebuah masalah, maka ucapan nabi adalah hak yang memutuskan, dimana konsekwensi dari keputusan tesebut harus ditaati dan tidak pendapat lain, dalam artia ucapan nabi adalah Haq: yang paling benar. Dalam al-Quran jelas diperintahkan, sebagai mana firman Allah Swt. di Q.S. an-Nisaa' : 59 :

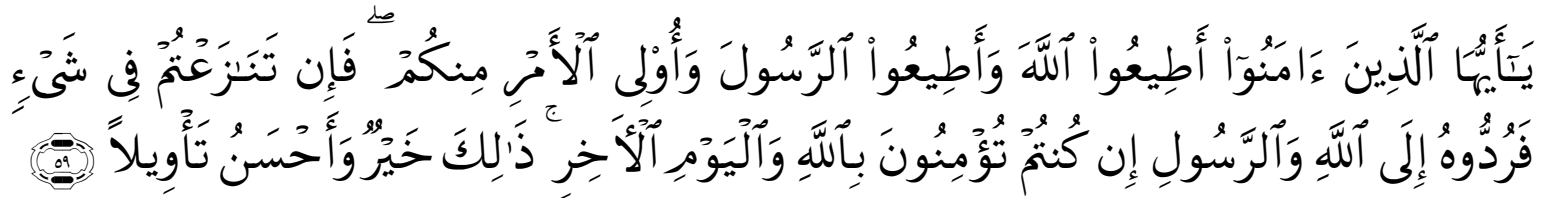

Terjemah :

Hai orang-orang yang beriman, taatilah Allah dan taatilah Rasul (Nya), dan ulil amri di antara kamu. kemudian jika kamu berlainan Pendapat tentang sesuatu, Maka kembalikanlah ia kepada Allah (Al Quran) dan Rasul (sunnahnya), jika kamu benar-benar beriman kepada Allah dan hari kemudian. yang demikian itu lebih utama (bagimu) dan lebih baik akibatnya. ${ }^{2}$

Sesudah Nabi wafat, dalam sejarah Islam telah tercatat bahwa persoalan yang mulamula muncul adalah persoalan politik, bukan dalam bidang teologi, meskipun dari persoalan politik inilah yang mengawali persoalan teologi, ${ }^{3}$ implikasinya pada umat Islam adalah munculnya faham yang berbeda-beda mengenai beberapa pokok agama yang kembali kepada iman dan keyakinan kaum muslim hingga kini.

\footnotetext{
${ }^{1}$ Dosen Tetap Prodi BPI IAIM Sinjai

${ }^{2}$ Depag RI, Al-Quran dan terjemahnya (Cet...; Jakarta:CV Penerbit J-ART, 2005), h.

${ }^{3}$ Harun Nasution, Teologi islam:aliran-aliran sejarah dan Pebandingan (Cet. I; Jakarta: UI Press, 1986), h. 1
} 
Persoalan politik yang kemudian berubah menjadi masalah teologi berawal dari keluarnya sekelompok pendukung Ali Bin Abu Thalib yang memisahkan diri dari pasukan Ali sebab ketidak puasan mereka menerima tahkim;arbitrase yang dilakukan Ali dan Muawiyah dalam perang Siffin, mereka kemudian dikenal sebagai kaum Khawarij. Menurut mereka penyelesain sengketa (perang) dengan jalan Tahkim bertentangan dengan apa yang ditentukan Tuhan, dan karena itu orang-orang yang terlibat di dalamnya antara lain Ali, Muawiyah, Abu Musa Al Asyari, Amr Bin Ash dan orang-orang yang telah menyetujui Tahkim tersebut telah menjadi kafir. ${ }^{4}$ Dari sini muncul pertanyaan yang menarik untuk dikaji dan didiskusikan, siapakah yang berada di atas kebenaran ? dan siapa yang berada dalam kebathilan ? dan apabila seseorang bersikap netral terhadap dua kelompok, maka hujjah apakah yang dipegangnya dalam pilihannya itu ?.

Terkait dengan pertanyaan-pertanyaan tersebut, H. A. Mustafa dalam bukunya “" Filsafat Islam" menulis, sebagai berikut :

Orang tidak akan dapat mempelajari masyarakat kaum muslimin yang aneka ragam, kalau tidak mempelajari sejarah agama Islam dan hukum Islam, demikian pula jika ia tidak mengerti perbandingan aliran atau mazhab, yang ditimbulkan oleh perbedaan cara berfikir atau berfilsafat. ${ }^{5}$

Untuk itu, dalam makalah ini penulis akan membahas sejarah munculnya dan pokok-pokok ajaran khawarij dan Murjiah, serta sekte-sekte yang timbul dari keduanya, sebab menurut para sejarahwan dan teolog, berpendapat bahwa cikal bakal perbedaan umat Islam sampai sekarang ditengarai awalnya karena kedua aliran ini.

\section{Sejarah, Pokok-Pokok Ajaran, Sekte Al- Khawarij dan Al-Murjiah}

\section{A. Al-Khawarij}

\section{Sejarah Timbulnya}

Kelompok ini muncul pada waktu terjadi perang Siffin ketika Ali dan Muawiyah menyetujui dua orang hakim penengah, dari pihak Ali diwakili oleh Abu Musa al Asyari dan pihak Muawiyah diwakili Amr Bin Ash, peristiwa inilah yang dikenal dengan Tahkim. Dalam dialog ini, mereka sepakat menjatuhkan keduanya -Ali dan Muawiyah- sebagai

\footnotetext{
${ }^{4}$ Harun Nasution, Islam di Tinjau Dari Berbagai Aspeknya (Cet. IV; Jakarta UI Press, 1986), h. 31.

${ }^{5}$ H. A. Mustafa, Filsafat Islam (Cet. IV; Bandung: Pustaka Setia, 1997), h. 42.
} 
Khalifah, namun ternyata diluar dugaan setelah Abu Musa al Asyari mengumumkan kesepakatan tersebut bahwa Ali mundur sebagai Khalifah namun kemudia ketika giliran Amr Bin Ash yang bicara justru mengumumkan bahwa menyetujui Ali mundur dan menolak penjatuhan Muawiyah sebagai khalifah. ${ }^{6}$

Sebelum hasil kesepakatan diumumkan oleh kedua wakil tersebut, ketika tahkim masih berlangsung sebagian dari para pendukung Ali tiba-tiba berbalik dan berkata " $k a l i a n$ semuanya telah menjadi kafir dengan memperhakimkan manusia sebagai ganti memperhakimkan Allah diantara kalian" ${ }^{\text {7 }}$. Mereka menyitir firman Allah pada Q.S. al Anfal: 39 , yaitu :

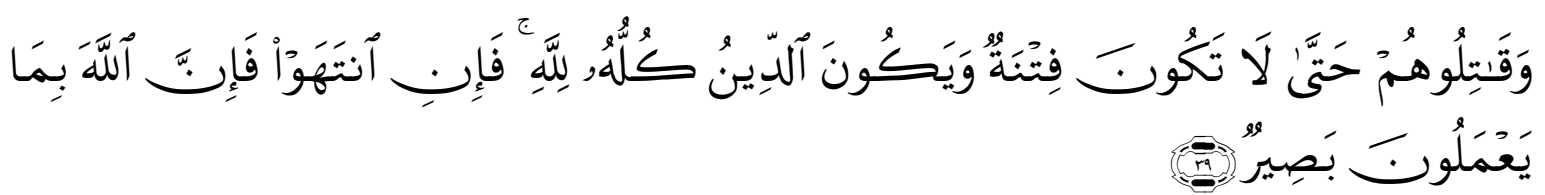

Terjemahan :

Dan perangilah mereka, supaya jangan ada fitnah dan supaya agama itu semata-mata untuk Allah. jika mereka berhenti (dari kekafiran), Maka Sesungguhnya Allah Maha melihat apa yang mereka kerjakan. ${ }^{8}$

Slogan mereka yang terkenal adalah La hukma illa lillah; tidak ada hukum kecuali milik Allah. Menurut mereka Ali adalah khalifah yang sah dan Muawiyah adalah aggressor yang membangkang, yang tidak layak untuk ditahkim. Dengan menyetujui Tahkim ini Ali melakukan dosa besar karena mengingkari ayat-ayat Allah, dan oleh sebab itu, ia mengeluarkan dirinya sendiri dari komunitas sejati orang beriman. ${ }^{9}$ Akhirnya merekapun meninggalkan barisan Ali dan membentuk kelompok sendiri, mereka inilah yang kemudian disebut khawarij yaitu orang yang keluar dari persatuan. Mereka keluar dan memisahkan diri dari barisan Ali dan Muawiyah. ${ }^{10}$

\footnotetext{
${ }^{6}$ Al- Thabari, Tarikh al Umam al Mulk (Beirut: Daar al Fikr, 1979)h. 71.

${ }^{7}$ Abul A'la al Maududi, Al Khilafah wal Mulk-terj.Muhammad al Baqir ( Cet. I; Kuwait; Daar al Qalam, 1978), h. 250

${ }^{8}$ Depag RI. Al-Quran dan terjemahnya...., h. 181.

${ }^{9}$ John L. Esposito- Ensiklopedi Oxford, Dunia Islam Modern (Cet. II; Bandung: Mizan, 2002), h. 204

${ }^{10}$ Tim Penyusun Ensiklopedi Nasional, Ensiklopedi Nasional (Cet, I jilid VIII; Jakarta: PT. Cipta Adi Pustaka, 1990), h. 469.
} 
Para pembangkang ini kemudian berkumpul di Harurah di terusan Nahrawan sehingga mereka disebut juga Haruri. ${ }^{11}$ Beberapa waktu kemudian mereka menjadi orangorang yang sangat ekstrem dalam pendapat-pendapat mereka dan sangat melampaui batas. ${ }^{12}$ Mereka muncul dengan kekuatan sebesar 4.000 pasukan dibawah pimpinan Abdullah ibn Wahb al-Rasibi. Di tepi kanal Nahrawan, Ali menyerang barak mereka (659M) dan hamper memusnahkan mereka, tapi mereka kembali muncul dengan berbagai macam nama dan tetap menjadi duri bagi kekhalifaan hingga masa dinasti Abbasiyah. Pada 24 Januari 661, ketika Ali dalam perjalanan menuju mesjid Kufah, ia terkena hantaman pedang beracun di dahinya. Pedang tersebut mengenai otaknya, diayunkan oleh pengikut Khawarij, abd al-Rahman ibn Muljam, yang ingin membalas dendam atas kematian keluarga seorang wanita, temannya yang terbunuh di Nahrawan. ${ }^{13}$ Kekuatan terbesar mereka terpusat di Iraq, benteng terbesar dan terkuat mereka di daerah Bathaih antara basrah dan kufah. Oleh sebab, dalam waktu yang lama sekali mereka telah membangkitkan keonaran;anarkisme di mana-mana dan lebih cenderung membunuh dan menumpahkan darah, maka pada zaman Dinasti Abbasiyah berkuasa mereka ditumpas dan dimusnahkan. ${ }^{14}$

\section{Pokok-pokok ajaran}

Meskipun mempunyai banyak nama, namun nama Khawarij adalah nama yang popular selain selain kaum Hariri, mereka inilah mazhab teologi pertama yang muncul dalam Islam. Khawarij terkenal karena ketidaksudian dan kengganan mereka berkompromi, mereka menganggap dirinya sebagai satu-satunya komunitas muslim yang paling benar. Basrah adalah pusat intelektual kaum Khawarij, yang mempunyai pengikut di Arab selatan dan Mesopotamia hulu, tentara Arab membawa doktrin Khawarij ke Afrika utara, yang kemudian doktrin tersebut dominan dikalangan muslim suku Berber. ${ }^{15}$

${ }^{11}$ John L. Esposito, Ensiklopedi Oxford, Dunia Islam Modern..., h. 205.

${ }^{12}$ Abu A'la al Maududi, Al Khilafah wal Mulk-terj.Muhammad al Baqir..., h. 251.

${ }^{13}$ Philip K. Hitti, History Of The Arabs-terj.R.cecep lukman yasin dan Dedi Slamet Riyadi (Cet. I; Jakarta: 2008), h. 226-227.

${ }^{14}$ Abu A'la al Maududi, Al Khilafah wal Mulk-terj.Muhammad al Baqir...., h. 251

15 John L. Esposito, Ensiklopedi Oxford, Dunia Islam Modern...., h. 205. 
Abu A'la al Maududi dalam kitabnya al-Khilafah wal Mulk yang diterjemahkan oleh Muhammad al Baqir menuliskan intisari doktrin dan Dogma ( pendapat dan ajaran keyakinan) kaum Khawarij sebagai berikut :

1. Mengakui keabsahan kekhalifaan Abu Bakar dan Umar. Adapun Usman telah menyimpang pada akhir masa khilafahnya dari keadilan dan kebenaran, karena selayaknya dibunuh atau dimakzulkan, Sedangkan Ali telah melakukan dosa besar dengan bertahkim selain Allah. Demikian pula Umayyah, Abu Musa, Amr bin Ash, semua adalah orang-orang berdosa, selain itu semua orang yang ikut dalam perang Onta, termasuk Thalhah, zubair dan Aisyah Ummul Mukminin, telah melakukan dosa besar.

2. Dosa sama dengan kekufuran. Pelaku dosa besar adalah kafir apabila tidak bertobat. Atas dasar pendapat inilah mereka terang-terangan mengkafirkan sebagian sahabat Nabi Saw., selain itu mereka juga mengkafirkan kaum muslimin keseluruhan karena pertama, mereka tidak suci dari dosa-dosa, kedua, kaum muslimim umumnya menganggap para sahabat nabi tersebut sebagai imam serta menetapkan hokum syariat dengan hadits-hadits yang diriwayatkan dari sahabat Nabi tersebut.

3. Khilafah tidak sah kecuali adanya pemilihan bebas antara kaum muslimin dan tidak dengan cara apaun selain itu

4. Tidak setuju dengan pendapat bahwa seorang khalifah harus berasal dari suku Quraisy. Seorang laki-laki yang saleh apabila dipilih oleh kaum muslimin maka dapat menjadi khalifah.

5. Ketaatan kepada khalifah sesuatu yang wajib hukumnya selama ia berada di jalan kebaikan dan keadilan, apabila menyimpang maka wajib memeranginya, memakzulkannya, bahkan membunuhnya.

6. Menerima al Quran sebagai salah satu sumber hukum selain hadits dan ijma', mereka memiliki cara yang berbeda dengan cara kaum muslimin lainnya. ${ }^{16}$

\section{Sekte-sekte Khawarij}

Sepintas kaum Khawarij begitu kompak dan besatu sehingga kuat namun kenyataannya dalam perkembangan intern mereka terjadi juga perpecahan yang menjadi subsekte khawarij. Menurut asy- Syahrastani, mereka terpecah menjadi 18 subsekte dengan 8 sekte utama, yaitu al-Muhakkimah, al-Azariqah, al-Najdaat, al-Baihasyiyah, alAjaaribah, al-Tsa'alibah, alibadiyah, dan al-Sufriyah ${ }^{17}$. Berikut nama sekte khawarij antara lain, yaitu :

\footnotetext{
${ }^{16}$ Abu A'la al Maududi, Al Khilafah wal Mulk-terj.Muhammad al Baqir...., h. 251-256.

${ }^{17}$ Asy-Syahrastani, Al-Milal wa Al-Nihal (Jilid I;al_qahirah: Muassasah al-Halaby, 1967), h.115.
} 
a. Al-Muhakkimah, adalah Khawarij asli, bagi mereka semua yang menyetujui tahkim bersalah dan menjadi kafir, selanjutnya hokum kafir ini diluaskan artinya sehingga termasuk bagi tiap orang yang berbuat dosa besar, misalnya berzina dan membunuh. $^{18}$

b. Al-Azariqah, Adalah golongan yang dapat menyusun barisan baru dan besar lagi kuat kurang lebih 20.000 pengikut setelah al Muhakkimah hancur. Pendirinya Nafi ibnu Azraq, ia dikenal sebagai panglima perang yang perkasa dan berani, sehingga pengikutnya member gelar amirul Mu'minin, Nafi terbunuh dalam pertempuran melawan pasukan Abdullah ibn Zubair, sekte inipun dhancurkan oleh dinasti Umayyah masa al-hajjaj. ${ }^{19}$ Sekte ini tidak lagi menggunakan term kafir tetapi Musyrik, musyrik dalam Islam merupakan dosa yang paling besar melebihi dosa kafir bahkan tidak diampuni oleh Allah. Yang dimaksud dengan musyrik pada sekte ini adalah semua orang yang tidak sepaham dengan mereka, bahkan orang islam yang sepaham dengan Azariqah tetapi tidak mau berhijrah kedalam lingkungan mereka juga dianggap musyrik. Selain itu bagi pezina tidak wajib dirajam karena menurut mereka al-Quran tidak mewajibkan. ${ }^{20}$

c. Al-Najdaat, Nama sekte ini dinisbatkan pada pendirinya yaitu Najdaat ibn Amir al-Hanafy. Sekte ini berpendapat bahwa setiap muslim wajib mengetahui Allah dan Rasul-Nya, wajib tahu tentang haram membunuh orang Islam yang mempercayai seluruh risalah Nabi, sedangkan orang-orang yang tidak mengetahui hal-hal tersebut tidak dapat dimaafkan. Seterusnya mereka berpendapat bahwa orang Islam yang tidak sepaham dengannya akan masuk neraka dan kekal di dalamnya, sedangkan golongan mereka yang melakukan dosa besar akan diazab tetapi bukan di Neraka, dan akhirnya juga masuk surga ${ }^{21}$. Golongan ini pula yang

${ }^{18}$ Harun Nasution, Aliran-aliran Islam-sejarah analisa perbandingan (Cet. II; Jakarta: UI Press, 2002), h.15-16.

${ }^{19}$ Al-Asy'ari Abi al-Hasan Ibn Ismail, Maqalat al-Islamiyah wa Ikhtilaf al-mushallin (Jilid I; alQahirah: Maktabah al-Nahdah al-Misrhriyah,1950), h. 157-196

${ }^{20}$ Harun Nasution, Aliran-aliran Islam-sejarah analisa perbandingan ...., h. 150.

${ }^{21}$ Syahrastani, Al-Milal wa Al-Nihal...., h. 123. 
membolehkan Taqiyah yaitu menyembunyikan identitas sebenarnya untuk keamanan diri, baik dalam bentuk perkataan maupun perbuatan. ${ }^{22}$

d. Al-Ajaaridah, Komunitas ini merupakan pengikut Abdul Karim Ibn Arjaad. Mereka berpendapat bahwa anak kecil tidak bersalah dan tidak musyrik seperti orang tuanya. Bagi mereka harta rampasan perang adalah milik orang yang sudah mati terbunuh, yang agak ekstrim mereka tidak mengakui salah surah dalam alQuran yaitu Surah Yusuf, karena hanya dalam surah ini ada kisah cinta, hemat mereka tidak pantas al-Quran sebagai kitab suci bercerita cinta;asmara. ${ }^{23}$

e. Al-Sufriah, Pemimpin golongan ini ialah Ziad Ibn al-Asfar, antara lain pendapat mereka sebagai berikut :

1. Orang Sufriah yang tidak berhijrah tidak dipandang kafir.

2. Mereka tidak berpendapat bahwa anak-anak kaum musyrik boleh dibunuh

3. Tidak semua diantara mereka berpendapat bahwa orang yang berbuat dosa besar menjadi musyrik .

4. Daerah muslim yang tidak sepaham dengan mereka bukan Daar Harb; daerah yang Harus Diperangi, Yang Diperangi Adalah Ma'askar Atau Camp Pemerintah, Sedan anak-anak dan perempuan tidak boleh jadi tawanan.

5. Kurf dibagi dua, kurf bin inkar al-ni'mah yaitu mengingkari rahmat Tuhan dan kurf bi inkar al-Rububiah yaitu mengingkari Tuhan. Jadi tidak selamanya term kafir harus berarti keluar dari Islam. ${ }^{24}$

f. Al-Ibadhiyah, Golongan ini merupakan golongan yang paling moderat, pendirinya Abdullah Ibn Ibad pada tahun $686 \mathrm{M}$, antara lain paham mereka yaitu ;

1. Orang Islam yang tidak sepaham dengan mereka bukanlah mukmin dan bukanlah musyrik, tetapi kafir

2. Daerah orang islam yang tak sepaham dengan mereka kecuali camp pemerintah merupakan dar tauhid; daerah yang mengesakan Tuhan dan tidak boleh diperangi

\footnotetext{
${ }^{22}$ Ahmad Amin, Fajr Islam (al-Qahirah: al-Maktabah al-Mishriyah, t.th.), h. 260.

${ }^{23}$ Ahmad Amin, Fajr Islam...., h. 163-164.

${ }^{24}$ Harun Nasution, Aliran-aliran Islam-sejarah analisa perbandingan ...., h. 21.
} 
3. Orang islam yang berbuat dosa besar adalah Muwahhid; yang meng-Esa-kan Tuhan, tetapi bukan mukmin dan bukan kafir al millah; kafir agama.

4. Yang boleh dirampas dalam perang hanyalah kuda dan senjata, emas dan perak harus dikembalikan kepada yang empunya. ${ }^{25}$

\section{B. Murjiah}

Kata Murji'ah berasal dari bahasa Arab, akar katanya adalah Arja'a yang berarti menunda atau menangguhkan ${ }^{26}$ menurut Abi Al-Fath Muhammad Abdul Karīm Ibn Abi Bakar Aḥmad Asy-syahrastānī, ada dua ma'na kata arja'a yaitu:

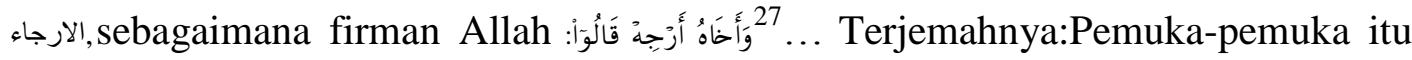

menjawab: "Beri tangguhlah dia dan saudaranya ........ اعطاء الرجاءartinya memberi harapan, ${ }^{28}$ yaitu memberi harapan pada pelaku dosa besar untuk memperoleh pengampunan dan rahmat Allah. Oleh karena itu, Murji'ah artinya orang yang menunda penjelasan kedudukan seseorang yang bersengketa, ya'ni 'Ali dan Mu'āwiyah serta pasukannya masing-masing kehari kiamat kelak. ${ }^{29}$

\section{Sejarah Timbulnya}

Setelah 'Uśman bin 'Affān mati terbunuh, banyak persoalan khilafah yang membawa perpecahan dikalangan umat Islam, seperti kaum khawārij yang mulanya adalah penyokong 'Ali, tetapi kemudian berbalik menjadi musuhnya. Karena adanya perlawanan ini, penyokong yang tetap setia padanya bertambah keras dan kuat membelanya, akhirnya mereka membentuk satu golongan lain dalam Islam yang dikenal dengan nama Syī'ah.

Kefanatikan golongan ini terhadap 'Ali bertambah keras, setelah ia sendiri mati terbunuh pula. Kaum Khawārij dan Syīah merupakan dua golongan yang bermusuhan,

${ }^{25}$ Harun Nasution, Aliran-Aliran Islam-Sejarah Analisa Perbandingan ..., h. 22.

${ }^{26}$ Atābik Ali dan Ah̆mad Zuhri Mahdlor, Kamus Al-Aşrīy ( Cet. V; Yogyakarta : Multi Karya Grafika, 1996), h. 76.

${ }^{27}$ Departemen Agama RI, Al-Qur'ān dan Terjemahnya (Semarang: Toha Putra, 1989), h. 239.

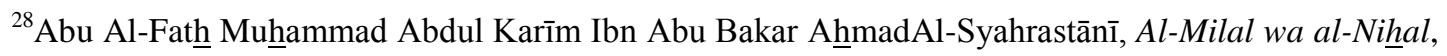
( Cet. II ; Beirut : Dār al-Fikr, 2002), h. 112.

${ }^{29}$ Rosihon Anwar, Ilmu Kalam ( Cet. II ; Bandung : Pustaka Setia, 2003 ), h. 56. 
namun sama-sama menentang kekuasaan Bani Umayyah, tetapi dengan motif yang berlainan. Khawārij menentang Dinasti Umayyah karena mamandang mereka menyeleweng dari ajaran Islam, Syì'ah menentang karena mereka menganggap merampas kekuasaan 'Ali dan keturunannya. Dalam suasana pertentangan serupa inilah, timbul suatu golongan baru yang ingin bersifat netral, tidak mau turut dalam praktek kafir-mengkafirkan yang terjadi antara golongan yang bertentangan itu. Bagi mereka sahabat-sahabat bertentangan itu merupakan oarang-orang dapat dipercayai dan tidak keluar dari jalan yang benar. Oleh karena itu mereka tidak mengeluarkan pendapat tentang siapa saja yang sebenarnya salah, dan memandang lebih baik menunda ( $A r j a ' a$ ), penyelesaian persoalan ini kehari perhitungan didepan Tuhan. ${ }^{30}$

Ada beberapa teori lain yang berkembang mengenai asal-usul kemunculan Murji'ah, diantaranya adalah :

a. Gagasan Irja' atau arja dikembangkan oleh sebagian sahabat dengan tujuan menjamin persatuan dan kesatuan umat Islam ketika terjadi pertikaian politik dan juga bertujuan untuk menghindari sektiarisme.

b. Teori lain mengatakan bahwa gagasan Irja' yang merupakan doktrin dari Murji'ah, muncul pertama kali sebagai gerakan politik yang diperlihatkan oleh cucu 'Ali Ibn

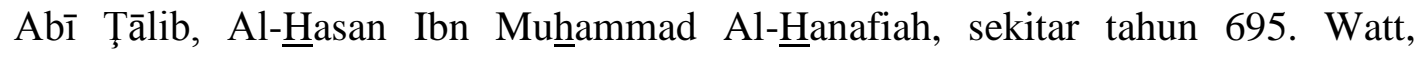
penggagas teori ini, menceritakan bahwa 20 tahun setelah kematian Mu'āwiyah pada tahun 680, dunia Islam dikoyak oleh pertikaian sipil. Al-Mukhtār membawa faham Syī'ah ke Kūfah dari tahun 685-687, Ibnu Zubair mengklaim kekhalifaan di Mekkah hingga yang berada dibawah kekuasaan Islam. Sebagai respon dari keadaan ini, muncul gagasan Irja' atau penangguhan. ${ }^{31}$

Teori lain menceritakan bahwa ketika 'Ali melakukan perseteruan dengan Mu'awiyah, dilakukan tahkim ( artibrase ) atas usulan 'Amr Ibn 'Ash, seorang kaki tangan Mu'āwiyah. Kelompok 'Ali terpecah menjadi dua kubu, yang pro dan yang kontra. Kelompok yang kontra akhirnya menyatakan keluar dari 'Ali, yakni kubu Khawārij. Mereka memandang bahwa tahkim bertentangan dengan Al-Qur'ān, dalam pengertian tidak

\footnotetext{
${ }^{30}$ Harun Nasution, Aliran-Aliran Islam-Sejarah Analisa Perbandingan ...., h.22.

${ }^{31}$ Harun Nasution, Aliran-Aliran Islam-Sejarah Analisa Perbandingan...., h. 23.
} 
bertahkim berdasarkan hukum Allah. Oleh karena itu, mereka berpendapat bahwa melakukan tahkim itu dosa besar, dan pelakunya dapat dihukumi kafir, sama seperti perbuatan dosa besar lain. Pendapat ini tentang sekelompok sahabat yang kemudian disebut Murji'ah, yang mengatakan bahwa pembuat dosa besar tetap mu'min, tidak kafir, sementara dosanya diserahkan kepada Allah, apakah dia akan mengampuninya atau tidak. $^{32}$

\section{Pokok-pokok ajaran}

Doktrin dikembangkan murji'ah ketika menanggapi persoalan-persoalan teologis yang muncul pada saat itu. Pada perkembangan berikutnya, persoalan yang ditanggapinya menjadi semakin kompleks sehingga mencakup iman, kufur, dosa besar dan dosa kecil, tauhid, tafsir al-Qur'ān, pengampunan terhadap dosa besar, kemaksuman nabi, nama dan sifat Allah, hakikat al-Qur'ān dan lain-lain.

Namun dalam kaitan teologi mereka menurut Harun Nasution pokok ajaran murjī'ah dikolompokkan menjadi tiga yaitu: ${ }^{33}$

a. Menunda hukuan atas orang-orang yang berseteru yang terlibat dalam peristiwa tahkīm( 'Ali, Mu'āwiyah, 'Amr Ibn 'Ǎş dan Abu Mūsā al-'Asy'arī) dan menyerahkan kepada Allah dihari akhirat.

b. Meletakkan pentingnya iman daripada amal

c. Orang yang melakukan dosa besar tetap mukmin, dan memberikan harapan akan adanya ampunan dan memperoleh rahmat dari Allah.

Sementara itu, Rosihan Anwar mengutip dari Abu Ya'lā Al-Maudūdi bahwa pokok ajaran Murji'ah ada dua yaitu: ${ }^{34}$

a. Iman adalah percaya kepada Allah dan Rasulnya saja. Adapun amal dan perbuatan tidak merupaka suatu keharusan bagi adanya iman, dalam hal ini seseorang masih tetap dianggap beriman walaupun meninggalkan hal-hal yang difardukan dan melakukan dosa besar.

\footnotetext{
${ }^{32}$ Harun Nasution, Aliran-Aliran Islam-Sejarah Analisa Perbandingan...., h.23-24.

${ }^{33}$ Harun Nasution, Aliran-Aliran Islam-Sejarah Analisa Perbandingan ...., h. 25.

${ }^{34}$ Rosihan Anwar, Ilmu Kalam...., h. 59.
} 
b. Dasar keselamatan adalah iman semata. Selama masih ada iman dihati, setiap maksiyat tidak dapat mendatangkan madarat ataupun gangguan atas seseorang. Untuk mendapatkan pengampunan, manusia cukup hanya menjauhkan diri dari syirik dan mati dalam keadaan bertauhid.

\section{Sekte-sekte}

Menurut Al-Asy'arīy sekte-sekte Murji'ah secara keseluruhan ada dua belas yaitu: ${ }^{35}$

a. Al-Jahamiyah (pengikut Jahm Ibn Şafwan), mereka berpendapat bahwa iman itu adalah mengenal Allah dan Rasulnya dan semua apa yang datang dari Allah saja, dan selain dari mengenal Allah, seperti pengakuan dengan lidah, tunduk, cinta Allah dan Rasul, mengagungkan dan takut kepadanya serta beramal bukanlah termasuk iman.Mereka mengira bahwa kekufuran itu adalah tidak mengenal Allah. Mereka berkata pula jika seseorang mengenal Allah dengan hati, lalu mengingkari dengan lidahnya, maka dia tidak kafir karena keimanan dan kekafiran itu tempatnya dihati, bukan pada lidah atau anggota badan yang lain.

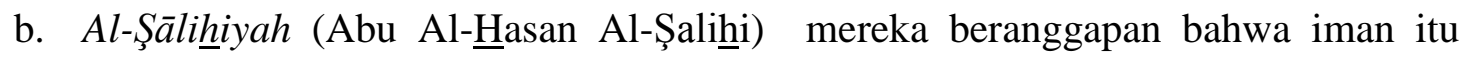
adalah mengenal Allah saja, sementara kekufuran adalah tidak mengenalnya, maka tidak ada keimanan tanpa mengenalnya dan tidak ada kekufuran kecuali tidak mengenalnya: Jadi kalau dikatakan ثالث ثلاثة (Allah salah satu dari tiga Tuhan) tidak kafir. Mereka pula berpendapat bahwa mengenal Allah itu adalah mencintainya yaitu tunduk kepadanya. Mereka berpendapat pula bahwa shalat itu لايزيد و bukanlah ibadah karena ibadah yang sesungguhnya adalah iman, iman juga

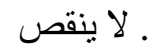

c. Al-Yūnusiyah ( Yūnus Al-Samariy ) mereka berpendapat bahwa iman itu adalah mengenal dan tunduk kepada Allah yaitu tidak takabbur kepadanya dan mencintainya, maka barangsiapa yang tidak takabbur dan mencintainya maka dia adalah mu'min. Mereka juga termasuk golongan syī'ah yang ekstrim, diyakini

\footnotetext{
${ }^{35} \mathrm{Al}-\mathrm{Imām}$ Abū al-Hasan 'Alī Ibn Ismā'īl al-Asy'arī, Maqālāt al-Islāmiyȳ̄n wa Ikhtilāf al-Muşallīn,juz I.(Bairut: al-Maktabah al-'Aşriyyah, 1995), h. 213
} 
bahwa Allah yang disembah itu diatas 'Arasy dibawa oleh para malaikat. ${ }^{36}$ Hal yang sama juga secara sepintas dikutip oleh Al-Sam'ān̄̄ dalam kitabnya : AlYūnusiyah mengira bahwa, iblis itu adalah orang yang beriman kepada Allah hanyaa saja dia kafir karena takabbur. ${ }^{37}$

d. Al-Syamariyah (Abu Syamr dan Yunus) mereka mengira bahwa iman itu adalah mengenal Allah dan tunduk kepadanya, mencintainya dengan hati serta mengikrarkan dengan hati bahwa Allah itu Esa dan tidak ada yang serupa dengannya.

e. Al-Şaubāniyyah (Abu Śaubān) mereka berpendapat bahwa iman itu adalah mengakui Allah dan Rasul-Rasulnyanya.

f. Al-Najjāriyyah ( pengikut Al-్usain Ibn Muhammad Al-Najjār ), Kelompok ini berpendapat bahwa Iman itu adalah mengenal Allah, Rasul-rasulnya dan kewajiban-kewajiban serta tunduk melaksanakannya, maka orang yang tidak mengetahui hal-hal tersebut atau mengetahui tapi tidak mengikrarkannya dia kafir. Seluruh kewajiban adalah iman maka melaksanakan sebahagian dari itu bukan ketaatan / iman, namun mereka tidak kafir. Menurut mereka bahwa iman itu bertambah dan tidak berkurang

g. Al-Gailāniyah (pengikut Abu Marwān Al-Gailān Ibn Marwān Al-Dimasyqū), mereka beranggapan bahwa Iman kepada Allah persoalan ke dua نظر و استدلال= penalaran) karena mau tidak mau tiap orang pasti mengenal Allah, jadi mengenal nabi dan apa-apa yang datang dari Allah serta apa yang disepakati oleh ummat Islam itulah yang disebut iman. Berkeyakinan pula bahwa الايمان لا يزيد و لا ينقص, tidak ada sesuatupun dari ajaran Agama yang mengeluarkan seseorang dari keimanan. Gailān berkata Iman itu membenarkan dengan lidah sementara mengenal Allah adalah perbuatan Allah, jadi iman tidak banyak atau sedikit karena iman hanya التصديق (membenarkan dengan lidah). Semua kelompok ini

\footnotetext{
${ }^{36}$ Al-Imām Abu Sa'ad Abdul Karīm Ibn Muhammad Ibn Manşūr Al-Tamīmīy Al-Sam'ānīy, AlAnsāb, Juz V, ( Cet. I; Bairut: Dār al-Fikr, 1988 M/1408 H ), h. 711

${ }^{37}$ Al-Imām Abu Sa'ad Abdul Karīm Ibn Muhammad Ibn Manşūr Al-Tamīmīy Al-Sam'ānīy, Al-Ansāb, Juz V...., h. 712.
} 
yaitu Jahmiyah, Syamariyah, Gailāniyah dan Najjāriyah mengingkari adanya iman bagi orang kafir. ${ }^{38}$

h. Syabībiyah (pengikut Muhammad Ibn Syabīb). Iman adalah iqrār dan mengetahui bahwa Allah itu Esa tidak ada sesuatu apapun yang serupa dengannya, serta iqrār kepada semua Nabi dan Rasul dan ajaran yang dibawanya seperti shalat dan puasa. Tunduk kepada Allah adalah tidak takbur, mereka yakin bahwa Iblis itu orang yang beriman hanya saja dia kafir karena takabbur, seandainya tidak takabbuar dia tidak kafir. Menurutnya الايمان يزيد و ينقص (mengimani sebahagian dan mengingkari sebahagian adalah kufur). Pelaku dosa besar tetep mukmin hanya saja dia fasiq.

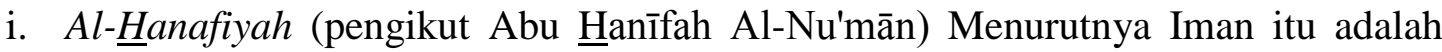
mengenal Allah dan mengEsakannya serta mengenal rasul serta apa yang dibawanya dari Allah secar keseluruhan. Iman tidak terbagi-bagi, tidak berkurang, tidak bertambah dan tidak ada yang lebih imannya diantara manusia. Sementara Gassān dan mayoritas pengikut Abu Hanīfah; Iman adalah Ikrar, cinta, mengagungkan, dan takut kepada Allah serta tidak meremehkanNya. Iman itu $\vee$

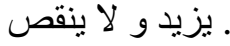

j. Al-Mu'áżiyah (pengikut Abu Mu'àż al-Taumī) Kelompok ini berpendapat bahwa iman itu adalah yang bebas dari kekufuran. Perintah fardu yang tidak dilaksanakan oleh seseorang yang diyakini kenarannya diangap seperti orang fasiq namun tidak boleh dipanggil fasiq, namun jika meninggalkan fardu seperti shalat, zakat, puasa karena mengingkarinya maka dianggap kekufuran.

k. Al-Murīsiyah (pengikut Basyr Al-Murīsī) Perkataan mereka bahwa iman itu adalah التصديق maka selain dari itu bukanlah kategori iman .Iman itu terletak pada hati dan lidah, sementara kekafiran adalah pengingkaran, tidaka boleh dikatakan kafir kecuali dikembalikan kepada asal bahasanya yaitu الجحد و الانكار. Demikian halnya iman, dikembalikan kepada asal bahasanya yaitu التصديق , maka tidak dikatakan iman jika tidak

${ }^{38}$ Al-Imām Abū al-Hasan 'Alī Ibn Ismā'îl al-Asy'arī, Maqālāt al-Islāmiyyīn wa Ikhtilāf alMuşallīn,juz I...., h. 217. 
diambil dari asal makna bahasanya. Mereka mengira bahwa sujud kepada matahari itu bukanlah kekufuran melainkan hanya tanda-tandanya, karena Allah menjelaskan bahwa tidak ada yang sujud kepada matahari kecuali orang kafir.

1. Al-Karāmiyah (pengikut Muhammad Ibn Karām) Keyakinan mereka bahwa iman itu adalah الاقرار و التصديق باللسان دون القلب (iqrār dan pembenaran lidah bukan hati), mereka mengingkari hati sumber iman. Mengatakan pula bahwa orang-orang munafik pada masa Rasulullah mukmin sejati, kekufuran adalah pengingkaran dengan lidah. Itulah sekte-sekte murji'ah, secara umum semua sekte tersebut sependapat bahwa: انه ليس فى احد من الكفار ايمان باله عز وجل (tidak ada iman kepada Allah bagi seorangpun dari kuffār ). Ada pula mengatakan: Ahlu Al-Qiblah tidak boleh dikatakan orang fāsiq meski telah jelas kefasakannya namun ada juga mengatakan fasak kalau memang perbuatannya terbukti.

Berdasarkan beberapa kutipan yang telah diuraikan, nampak bahwa penyebab kemunculan aliran-aliran pemikiran teologi Islam khususnya Khawarij dan Murjiah, diawali dengan adanya peristiwa yang bersifat politis. Peristiwa politis tersebut melahirkan perspektif yang berbeda-beda bagi sebagian kaum muslimin dalam menanggapi dan menyikapinya. Perspektif yang berbeda itu didasarkan pada pemahaman terhadap nashnash ajaran Islam yang selanjutnya menjadi alat legitimasi atas paham yang dianut.

Pada perkembangan selanjutnya, paham teologi Khawarij dan Murjiah mengalami perpecahan secara internal. Perpecahan ini melahirkan sekte-sekte yang biasanya merujuk kepada orang-orang tertentu yang menjadi pionir pengembang paham tersebut. Jika dikaji paham sekte-sekte tersebut, ada yang bersifat ekstrem dan demokrat. Selain itu, antara mereka penganut sekte-sekte tersebut terjadi persaingan pengaruh. Implikasi aliran teologi Khawarij dan Murjiah dalam Islam ini berekses pada perekembangan cara beragama umat Islam sampai hari ini. Khawarij menampakkan ajaran tekstual dengan pengejawantahan pemahaman yang cenderung keras dan kasar. Sedangkan Murjiah melahirkan sikap passif dan menghindari konfrontasi secara terbuka.

\section{Kesimpulan}


1. Khawarij adalah aliran teologi pertama dalam pemikiran Islam. Khawarij adalah pengikut Ali bin Abu Thalib ra. yang kemudian memisahkan diri dan membentuk komunitas sendiri, disebabkan mereka tidak setuju dengan Tahqim;arbitrase untuk menghentikan perang Siffin antara Ali dan Muawiyah.

2. Konsep inti ajaran Khawarij adalah term Kafir sebagai antitesa Iman. Konsep kafir merupakan ajaran dasar Khawarij dalam melihat persoalan teologi dan politik.

3. Munculnya Murji'ah merupakan reaksi terhadap aliran teologi yang sudah ada dan saling bertentangan bahkan saling menumpahkan darah karena fanatisme faham dan kelompok

4. Ajaran pokok Murji'ah adalah iman. Bagi mereka iman adalah satu-satunya kunci masuk surge, adapun amalan-amalan praktis keagamaan seperti shalat, puasa, zakat, dan sebagainya hanyalah merupakan kepatuhan dan ketaatan. 


\section{DAFTAR PUSTAKA}

Al-Quran dan Terjemahnya, Semarang: Toha Putra, 1989

Al-Qur'ān dan Terjemahnya, Cet I; Jakarta:CV Penerbit J-ART, 2005

al Maududi, Abul A'la. Al Khilafah wal Mulk-terj.Muhammad al Baqir Cet. I; Kuwait; Daar al Qalam, 1978.

Al- Thabari, Tarikh al Umam al Mulk Beirut: Daar al Fikr, 1979

Al-Syahrastān̄̄, Abu Al-Fath Muhammad Abdul Karīm Ibn Abu Bakar Aḥmad. Al-Milal wa al-Nihal, Cet. II ; Beirut : Dār al-Fikr, 2002

, Al-Milal wa Al-Nihal Jilid I;al_qahirah: Muassasah al-Halaby, 1967.

Al-Asy'ari, Abi al-Hasan Ibn Ismail. Maqalat al-Islamiyah wa Ikhtilaf al-mushallin Jilid I; al-Qahirah: Maktabah al-Nahdah al-Misrhriyah,1950.

Al-Sam'ānīy, Al-Imām Abu Sa'ad Abdul Karīm Ibn Muḥammad Ibn Manşūr Al-Tamīmīy. Al-Ansāb, Juz V, Cet. I; Bairut: Dār al-Fikr, 1988 M/1408 H.

Amin, Ahmad. Fajr Islam al-Qahirah: al-Maktabah al-Mishriyah, t.th.

Anwar, Rosihan. Ilmu Kalam, Cet. II ; Bandung : Pustaka Setia, 2003

Esposito, John L. Ensiklopedi Oxford, Dunia Islam Modern Cet. II; Bandung: Mizan, 2002.

Hitti, Philip K. History Of The Arabs-terj.R.cecep lukman yasin dan Dedi Slamet Riyadi Cet. I; Jakarta: 2008.

Mahdlor, Ahmad Zuhri dan Atābik Ali. Kamus Al-Aşrrīy, Cet. V; Yogyakarta : Multi Karya Grafika, 1996

Mustafa, H. A. Filsafat Islam Cet. IV; Bandung: Pustaka Setia, 1997

Nasution, Harun .Teologi islam:aliran-aliran sejarah dan Pebandingan Cet. I; Jakarta: UI Press, 1986.

----------------, Islam di Tinjau Dari Berbagai Aspeknya Cet. IV; Jakarta UI Press, 1986.

Tim Penyusun Ensiklopedi Nasional, Ensiklopedi Nasional Cet, I jilid VIII; Jakarta: PT. Cipta Adi Pustaka, 1990. 